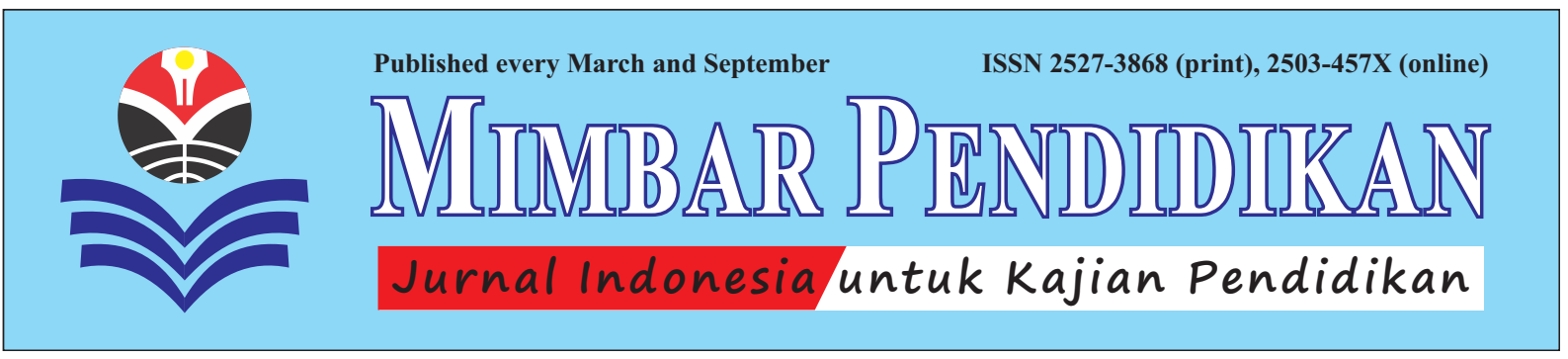

JENNY P. CRUZ \& NERISSA S. TANTENGCO

\title{
Students' Environmental Awareness and Practices: Basis for Development of Advocacy Program
}

\begin{abstract}
The descriptive study was used to identify the environmental awareness and practices of the selected students at the Sta. Elena High School in the Philippines. Findings revealed that based on the responses in the modified Environmental Awareness Scale, the respondents were moderately aware of the environmental concepts. In the participation in environmental programs, the respondents sometimes do the tasks of recycling; water and energy conservation; non-use of harmful products; creative possible solution; and social media solution. They seldom do the tasks of participating in tree planting and joining in school's environmental clubs. Students' interview revealed that in spite of the almost the same programs about environmental care cited by the officers of the different school clubs, not all of their schoolmates had initiatives in keeping the school campus clean. Through the guidance of their parents, the students participate in environmental practices at home. Accordingly, the teachers should strengthen the integration of environmental concepts, principles, and practices in various subjects in the school.

KEY WORD: Awareness; Environmental Awareness Scale; Environmental Advocacy Program; Environmental Problems; Social Media.
\end{abstract}

ABSTRAKSI: "Kesadaran dan Pengamalan Siswa tentang Lingkungan: Dasar untuk Pengembangan Program Advokasi". Kajian deskriptif ini digunakan untuk mengidentifikasi kesadaran dan praktek siswa terpilih di SMA (Sekolah Menengah Atas) Sta. Elena, Filipina. Temuan mengungkapkan bahwa berdasarkan tanggapan dalam Skala Kesadaran Lingkungan yang dimodifikasi, para responden cukup sadar akan konsep lingkungan. Dalam partisipasi program lingkungan, para responden kadang-kadang melakukan tugas-tugas daur ulang; konservasi air dan energi; tidak menggunakan produk yang berbahaya; solusi sekreatif mungkin; dan solusi media sosial. Mereka jarang melakukan tugas partisipatif dalam penanaman pohon dan bergabung di klub lingkungan sekolah. Para siswa mengungkapkan bahwa meskipun ada program yang hampir sama tentang perawatan lingkungan yang ditekankan oleh petugas dari klub sekolah yang berbeda-beda, tidak semua siswa sekolah memiliki inisiatif dalam menjaga lingkungan sekolah yang bersih. Melalui bimbingan orang tua, para siswa berpartisipasi dalam praktek menjaga lingkungan di rumah. Karena itu, guru harus memperkuat integrasi konsep lingkungan, prinsip, dan praktek dalam berbagai mata pelajaran di sekolah.

KATA KUNCI: Kesadaran; Skala Kesadaran Lingkungan; Program Advokasi Lingkungan; Masalah Lingkungan; Media Sosial.

About the Authors: Jenny Perez Cruz is the Araling Panlipunan (Social Studies) Department Coordinator of Sta. Elena High School at present in the Philippines. Nerissa S. Tantengco, Ph.D. is a Full Professor VI in the College of Teacher Development, Faculty of Behavioral and Social Sciences PNU (Philippine Normal University) in Manila, Philippines. Corresponding authors: tantengco.ns@pnu.edu.ph

How to cite this article? Cruz, Jenny Perez \& Nerissa S. Tantengco. (2017). "Students' Environmental Awareness and Practices: Basis for Development of Advocacy Program" in MIMBAR PENDIDIKAN: Jurnal Indonesia untuk Kajian Pendidikan, Vol.2(1) March, pp.43-64. Bandung, Indonesia: UPI [Indonesia University of Education] Press, ISSN 2527-3868 (print) and 2503-457X (online).

Chronicle of the article: Accepted (September 19, 2016); Revised (January 19, 2017); and Published (March 30, 2017). 


\section{INTRODUCTION}

Our environment is dynamic, constantly changing, and evolving in response to the conflicting demands of the people. As the world's population and the per capita consumption of natural resources increase, we will have an even greater effect on these environmental problems, exacerbating them further (Harris, 2004). The big issue that needs to be considered is whether we still have enough resources to meet the need of the present as well as the future generation.

The Philippines is one of the countries that are facing environmental challenges and issues. Scenarios like floods, due to heavy rain and poor solid waste disposal, are just some of the reasons of environmental degradation. This can be easily gleaned from the list of environmental concerns, which the DENR (Department of Environment and Natural Resources) does not tire in enumerating in its Annual Report other than what are being reported in the news at present. Foremost among these environmental concerns are the massive and continuing decimation of the country's forests, loss of biodiversity, air pollution, water pollution, poor solid waste disposal, and climate change concerns (Palmer \& Neal, 1994; Louka, 2006; and Ofreneo, 2012).

In 1998, the NEDA (National Economic Development Authority) noted under the Philippine National Development Plan: Directions for the $21^{\text {st }}$ Century the threats posted by an oscillating climate system, due to global warming which spawns destructive episodes of El Niño droughts and La Niña floods. This oscillating El Niño and La Niña weather pattern causes natural disasters, such as droughts, floods, and powerful storms. NEDA also noted that at the time that the tragedy of global warming is that although industrialized countries have caused bulk of historical and current emissions of greenhouse gases, it is highly likely that the most serious impact of global climate change will host the developing countries, like the
Philippines (Ofreneo, 2012; and Sering, 2013).

Because of these environmental concerns, the school system is one of the highly affected institutions. During typhoons or even heavy rains, classes' suspensions are expected, because of the flood. This is evident most especially in schools located near the river and other flood-prone areas. This situation can cause a big effect in the learning process of the students considering the fact that every time the classes are suspended, they will not learn anything due to the situation. Marikina City is one of the flood-prone areas in the National Capital Region, which is being monitored every time heavy rain occurs. It was one of the affected places during the typhoon Ondoy that hit the Philippines last September 26, 2010 (Reyes, 2009).

It is the purpose of this study to help in eliminating the problems brought by environmental degradation, particularly the damage caused by flood through the aid of investigating the students' environmental awareness and practices. Sta. Elena High School is one of the public schools in Marikina City that is the locale of this study. The school is the best venue in this study, because it is education which can make the human being conscious and knowledgeable about environment and environmental problems. Moreover, awareness is essential for action (Ajzen, 1991; Louka, 2006; and Kaur \& Kaur, 2013).

As our environment faces different problems, it might be too hard to support the needs of the future generation. The government regulators are in the right position to implement appropriate environmental laws, policies, and programs to avoid the massive destruction of our environment. Even the school system has its part in promoting environmental care. Education is a good medium for raising environmental awareness and honing environmental skills (Palmer \& Neal, 1994; and Agarwal \& Nangia, 2005). However, 
this has been given official attention only in recent years. The Catholic Association of the Philippines has integrated environmental studies Makabayan (Social Studies) and Science curriculum for high school students (cited Ofreneo, 2012), which can make even the young generation show their concern in taking care of the environment even in their own little way.

The subject of sustainable development is one of the key research and policy issues as we enter the early years of the twenty-first century (Brandon \& Lombardi, 2011). Sustainable development is the development that meets the needs of the present without compromising the ability of future generations to meet their own needs (Guzman et al., 2000). It has been acknowledged that there is no single route to sustainable development. Furthermore, it is coherent that understandings and visions for sustainability will be different for each of us and that we will need to work together to negotiate the process of achieving sustainability (Vega et al., 2009).

The Brundt-Land Commission was the first official commission to adopt the notion of sustainable development as a prerequisite for continued societal existence. It was mainly responsible for putting this notion on the international agenda (Opschoor \& Turner, 1994). It is everyone's responsibility to promote sustainable development. By having a program of action, it will be much easier to meet the goal of achieving a sustainable future. One of the programs of action is the Agenda 21, which aims for bringing the earth into a sustainable future into the $21^{\text {st }}$ century. It was adopted by the participating governments of the world in the UNCED (United Nations Conference on Environment and Development), otherwise known as the Earth Summit, in Rio de Janeiro, Brazil, in June 1992. ${ }^{1}$ Philippine Agenda 21 (PA 21)

\footnotetext{
${ }^{1}$ See, for example, "Agenda 21". Available online at: http:// sustainabledevelopment.un.org/content/documents/Agenda21. pdf [accessed in Manila, Philippines: September 21, 2016].
}

is our own national agenda for sustainable development. It is basically made up of the following: the Principles of Unity, the Action Agenda, and the Implementation Strategies. ${ }^{2}$

The World Youth Report, in 2003, cited that youth have both concerns and special responsibilities in relation to the environment. A number of environmental risks and hazards disproportionately affect young people, who have to live for an extended period with the deteriorating environment bequeathed to them by earlier generations. Young people will be compelled to engage in new forms of action and activism that will generate effective responses to ecological changes. ${ }^{3}$

An awareness of the different environmental problems is necessary most especially to the youth, who will be the hope of our future generation. Being aware of the present situation of the environment can help us achieve sustainability, but it can only be possible if we will also have action and reflection or a so called praxis (Freire, 1972), together with the environmental awareness or else, everything will just be a waste. The term "Environmental Awareness" has a broad connotation. Not only it implies knowledge about environment but also attitude, values, and necessary skills to solve environment related problem, and also is said to be the essential step ultimately leading to the ability to carry on responsible citizenship behaviour (Ajzen, 1991; and Sengupta et al., 2000).

In the UNESCO (United Nations Educational, Scientific, and Cultural Organization) Discussion Note for the Global Thematic Consultation on Environmental Sustainability in 2010, Education Millennium Development Goals (MDG 2 and 3) focus on access to education, but integrating education

${ }^{2}$ See also "The Philippine Agenda 21". Available online at: http://emb.gov.ph/eeid/philagenda.htm [accessed in Manila, Philippines: August 4, 2016].

${ }^{3}$ As cited in "World Youth Report in 2003". Available online at: http://www.un.org/esa/socdev/unyin/documents/ ch05.pdf [accessed in Manila, Philippines: October 14, 2016]. 
into MDG 7 is critical for achieving any environmental sustainability target (Agarwal $\&$ Nangia, 2005). Decisions and actions taken today have a decisive impact on the future. In order to take responsible decisions and actions, people need to have the relevant skills and knowledge, skills and values.

It is widely agreed that education is an indispensable vehicle for improving the possibilities for a sustainable society and for enhancing sustainable lifestyle (Scott \& Gough, 2003; and Arlemalm-Hagser, 2013), in which children are acknowledged as environmental stakeholders (the Philippine Agenda 21) with a right to meaningful participation in environmental issues. One key element that has been recognised is the importance of promoting a potentially life-long disposition towards caring for the environment among young children and youth (Davis \& Elliott, 2003; and ArlemalmHagser, 2013).

Conceptual Framework of the Study. Environmental awareness is necessary to solve environmental problems that we are facing at present. But, this awareness will be much effective if we put it into practice. The youth are supposed to be one of the best agents of change for they will be the new generation that will inherit the wealth of the environment (Agarwal \& Nangia, 2005; and Sering, 2013). Unfortunately, as the population grows, the environment cannot sustain its needs. Human-environment interactions are not just about meeting the global population's food needs, or even meeting natural resource needs. The human population also affects the environment through what it leaves behind.

As national populations grow and the demand for natural resources, particularly for food production and energy generation increases, worries that we shall exceed the resources of the planet have been expressed by many over the years. In this context, $\mathrm{F}$. Harris (2004) cited different populationenvironment theories, which support these assertions. One of his assertions is that Malthus predicted that human population growth would be checked by food supply. Thus, argument has been further developed by several authors ( $c f$ Harris, 2004; and Mukherjee, 2012).

According to F. Harris (2004), P.R. Erlich (1968) also argued that population growth rates at that time would exceed the world's resources. Furthermore, population growth and declining food production were found to occur in developing countries, they advocated population control (Erlich, 1968; and Harris, 2004). It was also cited by F. Harris (2004) that A.J. Bennett (2000) points out, that "there seems to be no evidence that our ability to produce food has been a lasting break on population growth" (Bennett, 2000; and Harris, 2004). In contrast, F. Harris (2004) also cited that T. Dyson \& C.Ó. Gráda (2002) maintains that production has increased and outstripped population growth in recent decades (Dyson \& Gráda, 2002; and Harris, 2004).

The UNESCO (United Nations Educational, Scientific, and Cultural Organization) Discussion Note for the Global Thematic Consultation on Environmental Sustainability, in 2010, cited that environmental sustainability cannot be achieved by scientific, engineering or technological solutions alone (Agarwal \& Nangia, 2005). It is education that enables learners to acquire the values, skills, and knowledge that allows equitable economic progress without depleting our natural resources (Soriano, 1995; Raven et al., 2010; and Enger \& Smith, 2013). This requires fostering environmental awareness as well as teaching about sustainability issues and promoting participatory teaching and learning methods that support critical thinking and collaborative learning.

The perspectives of Environmental Education seem to be, consecutively, related to positivism or knowledge about the environment; constructivism or activities 
in the environment; and the critical theory or actions for the environment of education (Robottom \& Hart, 1993). In this context, P. Madsen (1996) emphasized the concept that awareness is the ultimate driving force that stimulates knowledge. The acknowledgement that an environmental problem exist entails being more cognizant of the facts about the state of the environment (Madsen, 1996).

This degree of environmental awareness involves a personal commitment to work to solve environmental problems. P. Madsen (1996) emphasized the power behind the awareness factor by categorizing three levels of awareness as: basic belief of an environmental problem; factual and scientific knowledge; and a commitment to solve environmental problems (Madsen, 1996). One of the best ways to increase environmental awareness is to be a part in celebrating the Earth Day or the modern environmental movement. The idea of Earth Day was from the founder Gaylord Nelson, a USA (United States of America) Senator from Wisconsin, after witnessing the ravages of the 1969 massive oil spill in Santa Barbara, California. Inspired by the student anti-war movement, he realized that if he could infuse that energy with an emerging public consciousness about air and water pollution, it would force environmental protection onto the national political agenda. ${ }^{4}$

In order to solve environmental problems that we have, environmental practice must be looked upon. Environmental awareness will be an effective tool in achieving sustainability if it is concurred with positive practices towards environmental care. It is the "praxis", as defined by P. Freire (1972), which will lead to sustainability. It indicates life practice formed from both reflection and action. The self, striving to transform the world creatively according to an emerging

${ }^{4}$ See "Earth Day: The History of a Movement". Available online at: http://www.earthday.org/earth-dayhistory-movement [accessed in Manila, Philippines: October 5, 2016]. vision based on its own values, actualizes itself as actualizes its vision. ${ }^{5}$ There is a must to have not only practice, but praxis aside from having an environmental awareness; because praxis, as P. Freire defines, it is reflection and action upon the world in order to transform it (Freire, 1972).

The context of Environmental Education Praxis, according to D. Tilbury (1995) and cited also in J.E. Santos et al. (2000), discusses the opportunities of effective involvement of the community in the construction of the more responsible society in considering the implementation of Environmental Education about, in, and for the environment, incorporating the cognitive, affective and technical (participative) domains through the proposition of six basic stages: the awareness for obtaining ecological knowledge inserted in the process of educative competencies; interacting with the involvement of social actors, who through responsibilities, will look for action, and participation for the effective exercising of citizenship (Tilbury, 1995; and Santos et al., 2000).

Part of environmental problems is the environmental issues that we have. There are many environmental issues, such as global warming, climate change, environmental degradation due to pollution, and loss of biodiversity that endanger the environmental sustainability. These issues are intrinsically related to human behaviour (Gardner \& Stern, 2002). The Stern's Value Belief Norm Theory, as cited by K. Spehr \& R. Curnow (2011), believes that for those behaviours not strongly constrained by contextual forces, individual choice about pro-environmental actions can be driven by personal norms - an internalized sense of obligation to act in a certain way (Spehr \& Curnow, 2011).

Norms are activated when an individual believes that violating them would have

\footnotetext{
${ }^{5}$ As cited in "Encyclopedia of the Social and Cultural Foundations of Education, 2008". Available online at: http:// www.markfoster.net/struc/praxis.html [accessed in Manila, Philippines: October 5, 2016].
} 
adverse effects on things they value; and that by taking action, they would bear significant responsibility for those consequences. Karl Marx and Friedrich Engels, and also their political and social theory of Marxism, is one of the significant bodies of the nineteenth-century social theory in which the environment plays a particular role. Early Marxist theory was vehemently anti-ecological. Marxism expresses the thoroughly modern view that human social progress is dependent upon the exploitation and domination of non-human environment. Karl Marx can be seen as wanting to intensify the exploitation of the natural environment which Capitalism had begun, but end the exploitation of humans by humans and distribute the fruits of the exploitation of the environment more equally than under Capitalism (cited in Barry, 1999).

The appreciation of the regenerative and aesthetic qualities of the natural environment, which has its roots in Romanticism, was a view shared and extended by American transcendentalism of the late nineteenth century. This American movement in social and literary theory and practice was a form of nature religion/spirituality in that it saw God and spirituality as immanent in nature (Tietenberg, 2006; and Enger \& Smith, 2013). According to the transcendentalist view, the direct experience and appreciation of nature was a way to enter a higher or transcendental realm of eternal truth, beauty, and happiness, away from the mundane distractions of our everyday, urban world (cited in Barry, 1999; and Obar et al., 2012).

In the twentieth-century social theory, Jürgen Habermas (1968) has sought to show that the only relation we have with the natural environment is an instrumental one, governed by productive, prudential and technical concerns about how best we can exploit it. Jurgen Habermas does share with classical social theory is the Enlightenment belief that the progress and development of human society is premised on the exploitation and instrumental use of the natural environment ( $c f$ Habermas, 1968; and Barry, 1999).

In this study, the researchers believe that by having an environmental awareness and by performing positive environmental practices, environmental sustainability can be achieved. Hence, environmental advocacy must also be looked upon. As B. Primack (2004) cited, people have a responsibility to future generations (Primack, 2004). From a strictly ethical point of view, if we degrade the natural resources of the earth and cause the loss of biodiversity, future generations of people will have to pay the price in terms of a lower standard of living and quality of life.

Therefore, people of today should use resources in a sustainable manner so as not to damage species and communities. The youth of today must be challenged to play a big role in preserving the environment for their future needs. It is cited in chapter 25 of the Agenda 21 that:

\section{It is imperative that youth from all parts of the world participate actively in all relevant levels of decision-making processes, because it affects their lives today and has implications to their future. In addition to their intellectual contribution and their ability to mobilize support, they bring unique perspectives that need to be taken into account. ${ }^{6}$}

By having an environmental concern through an advocacy, the youth can help in preserving our environment. The Center for Democratic Education defines advocacy as a process which organisations and individuals use to exert pressure for changes in a specific policy or behaviour of government or institution. It is a fundamental process in a democratic society as it allows groups and citizens to influence public institutions and policy (cited in Everts et al., 1996). The

\footnotetext{
${ }^{6}$ See again "Agenda 21 ". Available online at: http:// sustainabledevelopment.un.org/content/documents/ Agenda21.pdf [accessed in Manila, Philippines: September $21,2016]$.
} 
term advocacy is used to describe a series of activities built around a theme or set of themes with the aim of effecting a specific change in action or policy. At the same time, advocacy processes of group formation and community organization, and build confidence at the local level (Brown, 2000; and Raven et al., 2010).

Effective environmental advocates are those who are able to create "intended, permanent, institutional change"; and those who remain committed, active, and motivated (Snow \& Benford, 1992; and Soriano, 1995). The USA EPA (United States of America, Environmental Protection Agency) developed a "Make a Difference in Your School", a guide to provide advice, ideas, and inspiration to teachers, school administrators, and others for planning a hands-on environmental day at school (cited in www. epa.gov/osw, 9/10/2016). The suggested activities in "Make a Difference in Your School" can be a basis for the development of an environmental advocacy program. In this study, the students' environmental awareness and practices were investigated and through the result of which an environmental advocacy program was formulated. The awareness of the environment covers the seven ecosystems, which are as follows: forest; freshwater; marine; urban ecosystem; land ecosystem; atmospheric condition; and biodiversity (Tietenberg, 2006; and Hoffman \& BoryAdams, 2010). The researchers assumed that the population of the study is aware with some of the concepts of the seven ecosystems. However, even if they might be familiar with the different environmental concepts, they may not be practising positive environmental practices that will help in preserving the environment.

The environmental practices, in this study, covers: recycling; tree planting and cleanup drive; water and energy conservation; participation in school's environmental club; non-use of harmful products; creative possible solution; and social media environmental exposure. The level of students' environmental awareness was measured through the use of Environmental Awareness Scale instrument by J. Canarias (2005). The instrument was adopted and modified by the researchers with their permission in order to suit the level of understanding of the fourth year level high school students and to include the present environmental problems and issues.

The Students' Environmental Awareness, which is based on the Modified Environmental Awareness Scale Instrument of J. Canarias (2005), is sub-divided into two levels. Level I consist of (1) Knowledge of environmental concept/state of environment; and (2) Knowledge of environmental issues/problem (Canarias, 2005). The knowledge of environmental concept/state of environment is regarded as the familiarity of the respondents on the facts about the ecology, latest policies, and laws about the environment; while the knowledge of environmental issues/problems is regarded as the familiarity of the respondents on the recent issues/problems, which are happening in the present which have caused the degradation of the environment. The interpretation of the responses can fall under highly aware, moderately aware, slightly aware, and not aware, depending on the mean that will be gathered in each item.

Level II of the Students' Environmental Awareness consists of the following:

(1) Awareness of the needs to formulate alternative solution; (2) Awareness of the need to take action in solving problems; and (3) Awareness of the need to possess a high degree of commitment and advocacy (Canarias, 2005). The awareness of the needs to formulate alternative solution is regarded as the familiarity of the respondents to make a wise choice in solving the environmental problems.

The awareness of the need to take action in solving problems is regarded as the praxis 
or the reflection and action of the respondents and on how they act upon in taking care of the environment. The awareness of the need to possess a high degree of commitment and advocacy is regarded as the familiarity of the respondents to their need to participate in the different activities and programs that will preserve the environment. The interpretation of the responses can fall under always does the task, sometimes does the task, seldom does the task, and not at all, depending on the mean that will be gathered in each item.

The conceptual paradigm of this study, as shown in figure 1, stresses that the main objective of this study is to know the level of environmental awareness of the selected $4^{\text {th }}$ year high school students. As presented above, P. Madsen (1996) pointed out that there are three levels of awareness; but in this study, the use of Environmental Awareness Scale which was modified from the instrument of J. Canarias (2005), level I and level II of the instrument were used.

The study also aims to know how the students demonstrated their environmental practices in their school and household by participating the different environmental practices, such as: recycling; tree planting and clean-up drive; water and energy conservation; school's environmental club; non-use of harmful products; creative possible solution; and social media exposure. By doing positive environmental practices, the students are helping in the preservation of the environment.

This can be supported by transdentalism, the view shared by the American Movement, as cited by J. Barry (1999) that by appreciation of nature, distraction of the urban world can be avoided which also shared the same assertion in the Stern's Value Belief Norm Theory, as cited by K. Spehr \& R. Curnow (2011). On the contrary, by having poor environmental practices, these students contributed to the exploitation of the environment which is supported by the social theories about environmental practices mentioned above, in which Karl Marx and Friedrich Engels, in the nineteenth century; and Jurgen Habermas (1968), in twentieth century, shared the same assertion that humans exploit the environment (cited in Habermas, 1968; and Barry, 1999).

The concept of the students' environmental awareness with the level I and II of the Environmental Awareness Scale is connected to the concept of environmental practices, because they are related with each other. The responses of the respondents in level I and II of the Environmental Awareness Scale are expected to be supported by the result of the interviews to the selected students, parents, and teachers. From the two constructs, there is an arrow pointing out to the different interpretations such as: highly aware; moderately aware; slightly aware; and not aware for level I; and always does the task; sometimes does the task; seldom does the task; and not at all for level II and for the students' environmental practices.

J.S. Gambro \& H.N. Switzky (1996) stressed that increased knowledge and understanding of environmental problems will lead to a more responsible behaviour as well as environmental activism (Gambro $\&$ Switzky, 1996). This supports why the environmental activities with high awareness are usually performed by the respondents. But, on the contrary, the responses in level I might also fall under moderately aware, slightly aware or even not aware about the concepts which resulted in sometimes does the task, seldom does the task or not at all of the environmental practices related in it as cited in level II.

The possible responses in level I, such as moderately aware, slightly aware, and not aware as well as the responses in level II, such as sometimes does the task, seldom does the task, and not at all are connected with an arrow to another construct which is the development of an advocacy program. The suggested activities in the EAP 


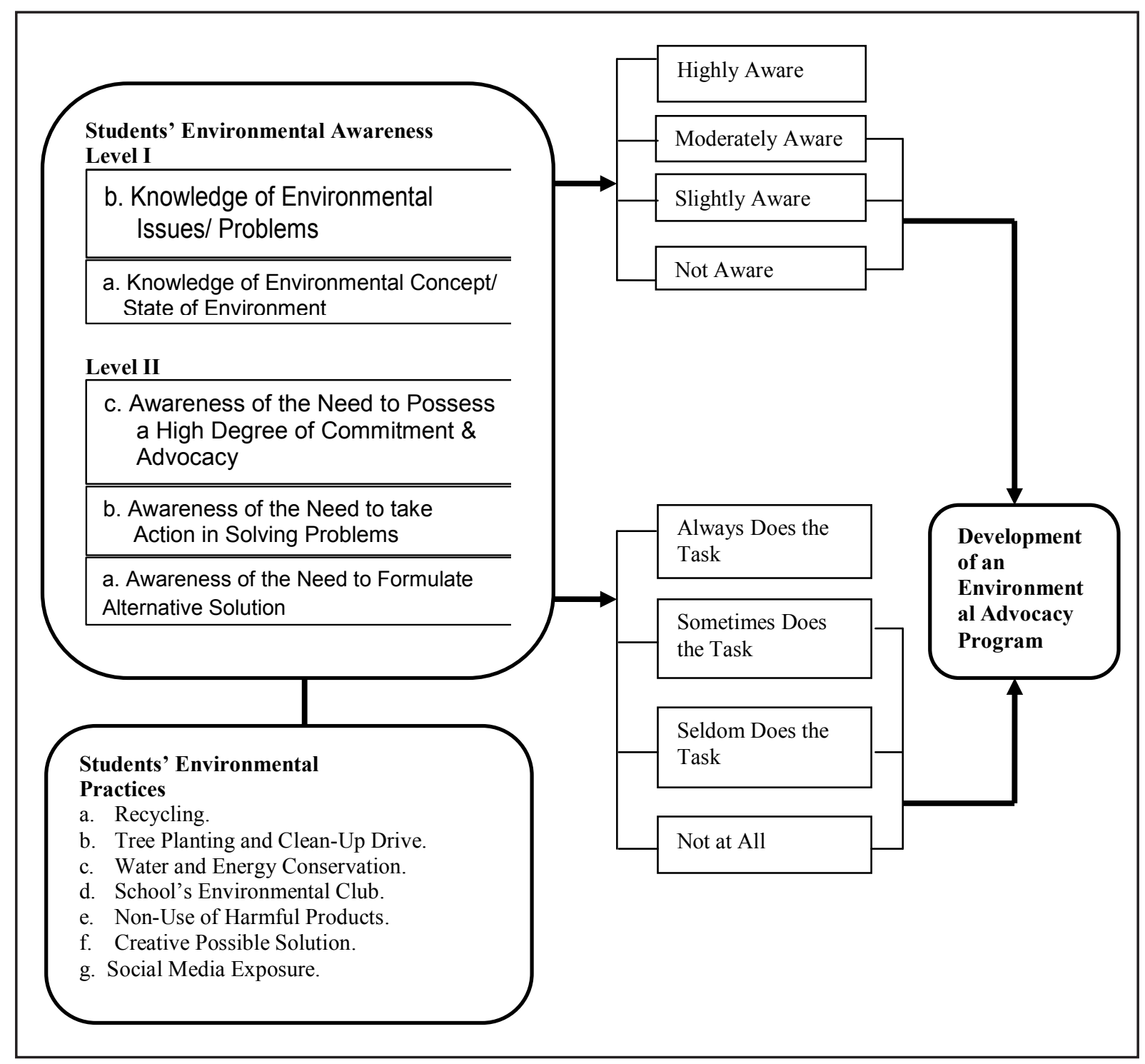

Figure 1:

Conceptual Paradigm of the Study

(Environmental Awareness Progam) will be developed to help the students to deepen their environmental awareness for the responses in level I with moderately aware, slightly aware, or not aware; and to increase their environmental practices for the responses in level II with sometimes does the task, seldom does the task, or not at all.

D. Tilbury (1995), as cited also in J.E. Santos et al. (2000), points out in the context of the Environmental Education Praxis mentioned above, the involvement of the social actors, through responsibilities, will look for action and participation upon having an awareness, knowledge and educative competencies (Tilbury, 1995; and Santos et al., 2000). Chapter 25 of the Agenda 21 supports the development of the EAP, because it believes that the youth must participate in the decision-making processes that will have in preserving the environment for their future (Santos et al., 2000; dan Tietenberg, 2006).

In making an EAP, items in the Environmental Awareness Scale that will gather a low mean will be the basis of what 
programs and activities that will be included. The EAP will help the students to be more aware of the condition of our environment. It will also encourage them to participate in different programs and activities that will deepen their environmental awareness and practices. The EAP is composed of 10 (ten) suggested programs and activities that aim to preserve the environment and deepen their environmental awareness and practices (Soriano, 1995; and Hoffman \& BoryAdams, 2010).

The following are the suggested programs and activities included in the EAP: (1) Symposium of the seven ecosystems; (2) Facebook Environmental Group; (3) Househouse Visitation for Giving Leaflets about the Environment; (4) Synchronized School Clean-Up Drive; (5) A Trip to Clean the Community; (6) Recycle Mania Competition; (7) Green Day; (8) Waste-Free Lunches; (9) Green Team; and (10) Environmental Fund Campaign Through Making a Product Out of Recyclable Materials (Soriano, 1995; and Sering, 2013).

\section{METHODS}

Discussions on the following topics are presented as follows: (1) the research method; (2) the participants; (3) the datagathering instrument; (4) time table of activities; and (5) the transcription and treatment of the data.

First, Research Method. The descriptive method of research was used in this study (Sevilla et al., 1984), which looked into the environmental awareness and practices of the selected fourth year students. After knowing the environmental awareness of the population, a structured interview was done with the selected students, teachers, and parents of the fourth year students.

N.K. Denzin \& Y.S. Lincoln (2003) cited that in structured interviewing, the interviewer asks all respondents the same series of preestablished questions with a limited set of response categories (Denzin \& Lincoln,
2003). The interviewer controls the pace of the interview by treating the questionnaire as if it were a theatrical script to be followed in a straightforward manner. Qualitative method is best to be used in order to describe the students' environmental practices at home and in school (Sevilla et al., 1984).

Second, the Participants. The participants of the study were fourth year high school students of Sta. Elena High School, School Year 2013-2014. The school is located in W. Paz St., Sta. Elena, Marikina City, Philippines. It is one of the public high schools in Marikina City, which is located at the heart of the city near the Marikina City Hall, Division City Schools Office, Marikina market, and other important establishments in the city.

The participants of the study were randomly selected 262 (two hundred and sixty two) students from a total fourth year population of 762 using the Slovin's formula with 5\% margin of error (cited in Sevilla et $a l .$, 1984). Male and female students were well represented. The list of students from the registrar's office was the basis in random sampling. To determine the total participants this formula was followed, as cited by J.F. Calderon \& E.C. Gonzales (1993).

$$
\begin{aligned}
& \mathrm{n}=\frac{\mathrm{N}}{1+}+\frac{\mathrm{Ne} 2}{\mathrm{~N}} \\
& \mathrm{n}=\frac{762}{1+762(0.05) 2} \\
& \mathrm{n}=\frac{762}{1+762(0.0025)} \\
& =\frac{762}{1+1.905} \\
& =\frac{762}{2.905}- \\
& =262.30 \text { or } 262 \text { students } 47 \text {. }
\end{aligned}
$$

$\mathrm{e}=$ desired margin of error (percent allowance for non-precision because of the use of the 
About 10 (ten) students' participants, who were officers and members of different school clubs/organizations, were selected for the in-depth interview to know their environmental activities in their club/ organization. About 6 (six) teachers were also chosen for interview to confer the students' environmental practices in and outside of the classroom. Two of their Social Studies teachers in third year level, two of their Social Studies in the fourth year level, and two Science teachers in the fourth year level were interviewed to support their responses in the Environmental Awareness Scale Instrument. To support the students' environmental practice at home, 5 (five) selected parents of fourth year students were visited and asked to answer a short interview.

Third, the Data-Gathering Instrument. The instrument used in this study is the EAS (Environmental Awareness Scale) by J. Canarias (2005), which is originally intended for second year high school students from the instrument done by E. Garcia (1997). The instrument was also modified by the researchers to give emphasis on the environmental problems and issues evident at present.

The researchers asked the permission of $\mathrm{J}$. Canarias to allow the researchers to use and revise some of the items in his Environmental Awareness Scale to give emphasis on the environmental problems and issues that we have at present. Upon the approval of J. Canarias, the researchers modified some of the items and asked the help of the experts to validate the instrument. The questionnaire, consisting of two levels, was prepared by the researchers and was validated by five environmental experts. The advisers of the researchers suggested to seek the help of the validators of the modified environmental awareness scale. Among the experts who validated the instrument were Dr. Enrico B. Garcia; Dr. Cristeta R. Dumadaug; Dr. Marie Paz E. Morales; Prof. Ronald Allan S. Mabunga; and Prof. Cristy S. Ocampo.
The instrument was written in Filipino, since it is the medium of instruction in Social Studies IV. Level I include knowledge of environmental concepts/state of the environment, issues, and problems. Level II includes the frequency of doing tasks, like formulating solutions, taking actions, and possessing a high degree of commitment to the environment. There are no right or wrong answers in the Modified Environmental Awareness Scale, but they will be the basis for determining the awareness of the respondents in the environmental problems and issues as well as the frequency of doing the environmental care tasks included in the instrument.

A 4-point Likert scale was used to indicate their responses in which point 1 signifies not aware; point 2 signifies slightly aware; point 3 signifies moderately aware; and point 4 signifies highly aware of the environmental concepts/state of the environment, issues, and problems in Level I of the modified environmental awareness scale. A 4-point Likert Scale was also used to indicate the responses in Level II in which point 1 signifies not at all; point 2 signifies seldom does the task; point 3 signifies sometimes does the task; and point 4 signifies always does the task, like formulating solutions, taking actions, and possessing a high degree of commitment to the environment.

Part I of the Modified Environmental Awareness Scale consisted of 20 (twenty) items, which has the same number from the scale of J. Canarias (2005). Sixteen 49 out of twenty items were revised by the researchers, which were as follows: item numbers $1,3,4$, $5,8,9,10,11,12,13,14,16,17,18,19$, and 20. Part II of the Modified Environmental Awareness Scale consisted of 30 (thirty) items which also has the same number from the scale of J. Canarias (2005), in which the researchers revised 19 (nineteen) items which were as follows: item numbers 21 , $26,27,28,29,30,31,33,35,37,40,41$, $42,43,44,45,46,47$, and 50. The revisions 


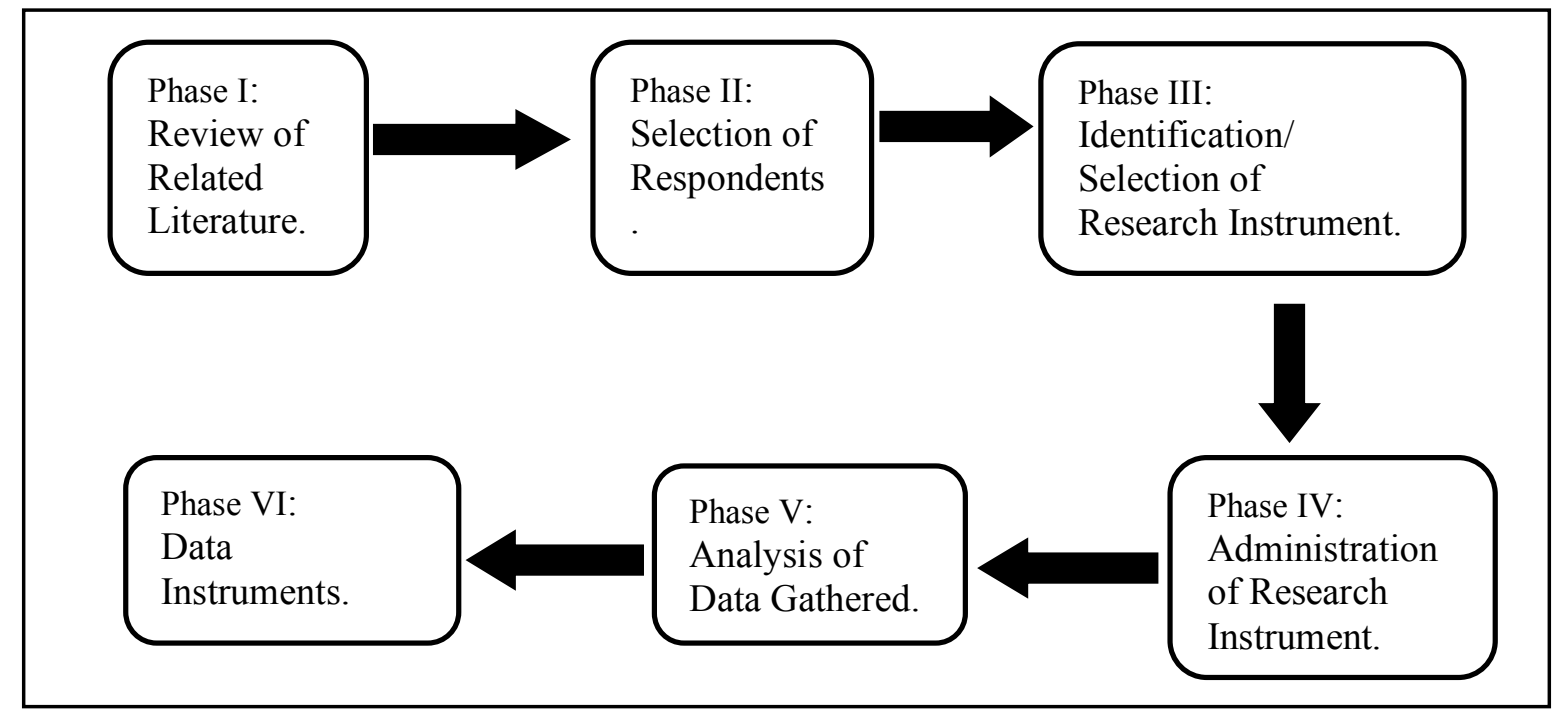

Figure 2:

A Flow Chart of the Procedures Undertaken in the Study

were done based on the suggestions given by the validators and to include the latest environmental concepts.

A table of specification was prepared by the researchers in order to determine the items presented in the environmental awareness scale. A follow-up interview with 10 (ten) fourth year students who were officers and members of different school organization, 6 (six) teachers, and 5 (five) parents with their children was conducted to support the responses of the students in the instrument. The questions were presented in Filipino to be able to make the respondents comfortable in answering it.

Fourth, the Time Table of Activities. Figure 2 shows the processes the researchers underwent in conducting the study. The following data gathering procedures were as follows: Phase I is the 50 Selection of Respondents; Phase II is the Identification/ Selection of Research Instrument; Phase III is the Administration of Research Instrument; Phase IV is the Analysis of Data Gathered; and Phase V is the Data Instrument.

Phase I: Review of Related Literature. Related topics about the environment and environmental practices were gathered and consolidated to serve as foundation of the present study.

Phase II: Selection of Respondents. Upon gathering of the related literature and having the idea on how the study will be done, the researchers decided to choose the fourth year level high school as the respondents of the study. The researchers chose the fourth year level, because of the assumption that among the other year level in high school; they are the most aware ones when it comes to environmental concepts and practices.

Likewise, six teachers from the third and fourth year level in the Social Studies and Science Department were chosen to be interviewed. This will further support the result of the respondents' responses in the Environmental Awareness Scale. In order to determine the environmental awareness at home, the researchers visited five parents and gathered data in a short interview.

Phase III: Identification/Selection of Research Instrument. Since there is already an available Environmental Awareness Scale instrument which was used by J. Canarias (2005) in his study, the selection of the research instrument was quite easy on the part of the researchers. However, 
the researchers sought the permission of $\mathrm{J}$. Canarias if he would allow her to modify some of the questions in the Environmental Awareness Scale. This stage was done from 7 October to 12 December 2013, which covered the period of asking permission from J. Canarias, modifying the instrument, and the validation of the five experts.

Phase IV: Administration of Research Instruments. The administration of research instrument started from 7 January 2014, in which the researchers sought the permission of the Division Superintendent of the DepEd (Department of Education) in Marikina, Philippines as well as the principal of the locale of the study. Parents' consent letters were also sent to the chosen respondents to know if they would be allowed to participate in the data-gathering. After the retrieval of all the parents' consent letters, the administration of the instrument was done from 13 to 15 January 2014. This was properly coordinated with the respondents' class adviser and their Social Studies teacher, because it was during this time the instrument was being administered.

The data gathered were analyzed through the help of Maribel Gerundio, in which the researchers asked her expertise in tallying the responses and doing the statistical treatment from 16 to 27 January 2014. From the prepared statistical treatment, the researchers began to analyze the result of the administration of the environmental Awareness Scale Instrument. The researchers studied and analyzed the table presented which showed responses of the respondents.

In the qualitative part of the study, the researchers prepared a parent consent letter asking for the permission if they can be interviewed during their most available time. Upon the approval of the five chosen parents, the schedules were set by the researchers. The researchers video-taped the on-going interview for the purpose of transcribing the responses. Photos were also taken for the additional documentation.
The analyses of the data gathered from the interview were done from 7 February to 31 March 2014. The researchers found it very hard to make an interpretation, because we needed to learn the categorization, thematizing, and coding of the interviewees' responses.

Phase V: Data Interpretation. After the analysis of the quantitative and qualitative data, the researchers started the data interpretation from 1-18 April 2014. In the quantitative part, each table was given an interpretation that reflects the result of the responses on the Environmental Awareness Scale instrument. While in the qualitative part, the result of the categorizing, thematizing, and coding of the interviews was used to interpret the data.

Phase VI: Formulation of the EAP (Environmental Awareness Program). The EAP was formulated based on the findings of the data gathered from the result of the administration of the Environmental Awareness Scale instrument and the interview. The researchers made an Environmental Awareness activities that can be done collaboratively by the different schools' organization in order to achieve environmental awareness and good environmental practices.

These activities are based on the result of the responses in the Environmental Awareness Scale instrument, in which the respondents got the weighted mean with an interpretation of sometimes does the task and seldom does the task, in which the researchers believe that needs to be enhanced. The formulated EAP was validated by the three validators. The formulation of the EAP was done from 19April to 6 July 2014.

Fifth, the Transcription and Treatment

of the Data. The data gathered from the instrument that was used in the study were treated with the use of frequency and weighted mean to measure the level of environmental awareness of the respondents. The weighted mean was used 
Table 1:

Weighted Mean and its Interpretation

\begin{tabular}{lcc}
\hline \multicolumn{1}{c}{ Level I: Interpretation } & Weighted Mean & Level II: Interpretation \\
\hline Highly Aware & $2.50-3.00$ & Always Does the Task \\
Moderately Aware & $1.50-2.49$ & Sometimes Does the Task \\
Slightly Aware & $0.50-1.49$ & Seldom Does the Task \\
Not Aware & $0.00-1.49$ & Not at All \\
\hline
\end{tabular}

in the computation of the scores per item in the level I and II of the instrument based from the responses of the students in the environmental awareness scale. This was the basis on how each item was interpreted as highly aware, moderately aware, slightly aware, and not aware for the level I of the instrument. The weighted mean in level II of the instrument was interpreted by always does the task, sometimes does the task, seldom does the task, and not at all.

The table 1 shows the weighted mean and its interpretation that was used in the gathered data of the study in level I and II of the instrument used.

The interviews of selected students, teachers, and parents were video-taped. Transcriptions were made based on the video-taped interviews. Thematizing, categorizing, and coding were done and were presented in tables for further analysis. The degree of their environmental practices was revealed through their responses to the questions prepared by the researchers, which was presented and approved by the two thesis advisers.

E. Babbie (1999) defines qualitative interview as an interaction between an interviewer and a respondent (Babbie, 1999). It is essentially a conversation in which the interviewer establishes a general direction for the conversation and pursues specific topics raised by the respond familiarity with data and attention to what is actually there rather than what is expected can facilitate realizations or ideas which emerge during analysis (Pope, Ziebland \& Mays, 2000; and Bailey, 2008).
Transcriptions of video-taped interviews were done by the researchers to be able to analyze the gathered data. Coding is a method that enables to organize and group similarly coded data into categories or families, because they share some characteristics (Saldana, 2008). In this context, G.B. Rossman \& S.F. Rallis (2003), as cited also in J. Saldana (2008), explain the differences between codes and themes: category is a word or phrase describing some segment of data that is explicit, whereas a theme is a phrase or a sentence describing more subtle and tacit process (Rossman \& Rallis, 2003; and Saldana, 2008). The present study coded, categorized, and thematized the transcribed interview which further gave a clear view and analysis of the gathered data.

An EAP (Environmental Advocacy Program) was produced by the researchers which is the outcome of the study. The EAP was validated by E. Garcia (1997), who has done studies about environmental awareness; Noemi Velario, who is a focal person from Parang High School in the implementation of environmental programs in the Schools Division of Marikina City; and Eugenia Martin, who is a Program Education Supervisor in DepEd (Department of Education) in Marikina, Philippines, who has done different writeups about school's environmental programs (Garcia, 1997 and 2000).

\section{RESULTS AND DISCUSSION}

Summary of Findings. The study aimed to formulate an environmental advocacy program based on the result of the students' participation in environmental programs 
and activities, and on how they demonstrate their environmental practices at home and in school. It employed the descriptive method of research (Sevilla et al., 1984). The modified Environmental Awareness Scale was used for gathering data after which she conducted a follow-up interview with selected students, teachers, and parents to supplement the respondents' responses in the instrument. The locale of the study is Sta. Elena High School, a public high school in Marikina City, Philippines. The instrument was administered to 262 (two hundred and sixty two) fourth year high school students, in which parent consents were given to the respondents of the study.

After tallying the result of the survey, the frequencies and weighted mean were computed to get the environmental awareness, and the frequency of doing the environmental tasks included in the instrument. The results of the responses in statement of the problem number 1 and 2 were the bases in the formulation of an overview of school's environmental advocacy program. Its vision is to strengthen students' environmental awareness and practices in their school, at home, and the community through strict implementation of guidelines and follow-up.

The draft was presented to the advisers of the researchers who looked into the content of the environmental advocacy program. The researchers also sought the suggestions of experts regarding the content of the environmental advocacy program. The experts who are inclined about the topic validated the environmental advocacy program. The following are the findings revealed in this study:

Firstly, the level of environmental awareness of the selected $4^{\text {th }}$ year high school students. Based on the data gathered from the instrument, the over-all weighted mean was 1.73, which signifies that the respondents were moderately aware of the knowledge of environmental/state of the environment which was revealed in sub-test I ( $c f$ Ato, 2002; Codeniera, 2003; Moralda, 2003; Mani, 2006; Gallardo, 2008; and Miranda, 2008).

It was supported by the result of the over-all weighted mean of sub-test II, which gathered 1.80 signifies that the respondents were moderately aware of the knowledge of environmental issues/problems ( $c f$ Domingo, 2007; Cadiao, 2009; and Desa et al., 2013).

The over-all weighted mean of sub-test I and II of level I which were gathered based from the responses in the modified Environmental Awareness Scale were very close with each other with only 0.07 difference, which proves that the respondents were moderately aware of the environmental concepts included in the instrument ( $c f$ Ato, 2002; Felipe, 2003; Mani, 2006; Miranda, 2008; and Paringit, 2012).

Secondly, the students' demonstration of their environmental practice at home and in school as an outcome of their awareness in terms of: recycling; tree planting and cleanup drive; water and energy conservation; school's environmental club; non-use of harmful products; creative possible solution; and social media exposure. It is revealed in the gathered data that the over-all weighted mean is 1.98 , which signifies that the respondents sometimes do the task of the activities related to recycling ( $c f$ Codeniera, 2003; Felipe, 2003; and Norris, 2013). While it is an over-all weighted mean of 1.32 , which signifies that the respondents slightly does the task of the activities which pertain to tree planting and clean-up drive ( $c f$ Valles, 2002; Domingo, 2007; Miranda, 2008; and Cadiao, 2009).

Under water and energy conservation, an over-all weighted mean of 2.15 was gathered which signifies that the respondents sometimes does the task related under these activities ( $c f$ Felipe, 2003; Sharmin, 2003; Miranda, 2008; and Norris, 2013). In school's environmental club, an over-all weighted mean of 1.39 was gathered which signifies that the respondents seldom does the task of participating in this activity ( $c f$ 
Fontanilla, 2003; Balmaceda, 2004; Gallardo, 2008; and Paringit, 2012).

Data gathered reveal that respondents sometimes do the task of non-use of harmful products with an over-all weighted mean of 1.94 (cf Miranda, 2008; Moralda, 2003; and Norris, 2013). In creative possible solution data reveal an over-all weighted mean of 1.82, which signifies that the respondents sometimes does the task regarding this activity (cf Fontanilla, 2003; Miranda, 2008; Cadiao, 2009; and Paringit, 2012). Finally, an over-all weighted mean of 1.57 , which signifies that the respondents sometimes does the task which pertains to social media exposure ( $c f$ Garcia, 2000; Codeniera, 2003; Sharmin, 2003; Mani, 2006; and Obar et al., 2012).

The students' interview reveal that in spite of the almost the same programs about environmental care cited by the officers of the different club officers, the interviewees believe that not all of their classmates/ schoolmates have initiative in keeping the school campus clean. They believed that their classmates/schoolmates fail to show environmental care, such as not throwing their trash in proper places most especially when no one sees them and not cleaning their table in the canteen after they ate their foods (interview with Student A, 9/2/2014; interview with Student B, 9/2/2014; interview with Student C, 9/2/2014; interview with Student D, 9/2/2014; and interview with Student E, 9/2/2014).

In the use of comfort rooms, they have observed that their schoolmates were not conserving water and some of the girls do not throw their sanitary napkins in its proper place. Vandalism, not taking care of chairs, as well as spitting which cause the spread of bacteria, was also seen as problems (interview with Student F, 16/2/2014; interview with Student G, 16/2/2014; interview with Student H, 16/2/2014; interview with Student I, 16/2/2014; and interview with Student J, 16/2/2014).

With regard to energy conservation, it is important to note that all of them are aware of the high energy fee consumption (cf Garcia, 2000; Ato, 2002; Moralda, 2003; Miranda, 2008; and Desa et al., 2013). This is because the principal discussed this matter to them and teachers were always reminding them (interview with Principal A, 23/2/2014; interview with Principal B, 23/2/2014; interview with Teacher A, 2/3/2014; interview with Teacher B, $2 / 3 / 2014$; and interview with Teacher C, 2/3/2014).

Awareness also came from the news about energy price hike ( $c f$ Valles, 2002; Balmaceda, 2004; Domingo, 2007; and Gallardo, 2008). They support the school by conserving energy through turning-off unnecessary lights and electric fan most especially during break time (interview with Principal C, 30/3/2014; interview with Principal D, 30/3/2014; interview with Teacher D, 9/3/2014; and interview with Student D, 9/2/2014).

The teachers' interview supported the same responses of the students' interview, which reveal that not all of their students show positive environmental practices. They need to be followed up from time to time, because not all of them show the initiative of keeping the surroundings clean (interview with Teacher D, 9/3/2014; interview with Teacher E, 9/3/2014; and interview with Teacher F, 9/3/2014). It was also evident that students were aware of the high energy consumption that made them show the initiative of conserving water and electricity when they are not in use (interview with Student F, 16/2/2014; interview with Student G, 16/2/2014; interview with Student H, 16/2/2014; interview with Student I, $16 / 2 / 2014$; and interview with Student J, 16/2/2014).

The interview with selected parents reveal that they guide their children in keeping the surroundings clean and avoiding the use of plastic, because they said they are highly aware of the penalty for using plastic most especially in the market. Some of them also practice recycling and one of 
them practices composting (interview with Parent A, 16/3/2014; interview with Parent B, 16/3/2014; and interview with Parent C, $16 / 3 / 2014$ ).

Other than recycling and water and energy conservation, most of them shared that they planting vegetables and ornamental plants to increase clean air in the surroundings. Through the guidance of their parents, the students participate in environmental practices at home (interview with Parent D, 23/3/2014; and interview with Parent E, 23/3/2014).

Thirdly, the EAP (Environmental Advocacy Program) developed to strengthen and deepen the environmental awareness and practices of the students. An environmental advocacy program was developed based on the findings in problems number 1 and 2 . This advocacy program aims to strengthen and deepen the students' environmental awareness and practices in their school, at home, and the community through strict implementation of guidelines and followup ( $c f$ Garcia, 2000; Fontanilla, 2003; Balmaceda, 2004; and Desa et al., 2013). This will be done through a collaborative effort of the different students' organization officers together with their adviser, school head, teachers, students, and parents ( $c f$ Valles, 2002; Sharmin, 2003; Miranda, 2008; and Cadiao, 2009).

\section{CONCLUSION}

Based on the findings of the study, the following conclusions are hereby drawn that the selected fourth year high school students manifested moderate awareness on the different concepts, issues, and problems of the environment. As an outcome of their awareness, students sometimes do the tasks, which pertain to recycling, water, and energy conservation; non-use of harmful products; creative possible solution; and social media exposure. However, they seldom do the tasks of tree-planting; clean-up drive; and participating to school's environmental club.
Different environmental practices were not demonstrated evidently by the students in their school, because most of them do not have the initiative to show environmental care without being seen and told by others. Teachers' follow-up sessions were needed for them to participate in keeping the surroundings clean. However, in energy and water consumption, students were totally aware of the negative effects it could bring which made them realize that they need to participate in the conservation. Thus, an environmental practice which regard to this activity was evident.

Environmental practices at home were demonstrated by the students together with their family members based on the result of the interview. This was because the parents were always reminding their children to take care of the environment through energy conservation and keeping the surroundings clean.

The items in the Environmental Awareness Scale with a low mean result with an interpretation of slightly aware under Level I and sometimes does the task as well as seldom does the task in Level II were the bases in developing an Environmental Advocacy Program.

The following are the recommendations based on the findings and conclusions drawn that the teachers should strengthen the integration of environmental concepts, principles, and practices in various subjects in the high school level. The school should institutionalize different environmental programs and projects for students as well as the teachers to actively participate in. Environmental programs and projects in the school and likewise in the community should be sustained through adequate funding, support of the teachers, and actively participation of various student organizations.

The extent of students' and teachers' knowledge about the environmental concepts can also be measured and compared with their environmental practices. The 
students' observation in the community's environmental activities might be included to further elaborate the environmental practices not only in school and at home. An in-depth study to explore other factors that hinder the students in actively participating in environmental care can also be done for further research. ${ }^{7}$

\section{References}

Agarwal, G. \& I. Nangia. (2005). Environmental Monitoring. New Delhi: APH Publishing Corporation.

"Agenda 21". Available online at: http:// sustainabledevelopment.un.org/content/ documents/Agenda21.pdf [accessed in Manila, Philippines: September 21, 2016].

Ajzen, I. (1991). "The Theory of Planned Behavior" in Organizational Behavior and Human Decision Processes, 50(2), pp.179-211. DOI: 10.1016/07495978(91)90020-T.

Arlemalm-Hagser, E. (2013). "Respect for Nature: A Prescription for Developing Environmental Awareness in Preschool". Available online at: http://www.pedocs.de/volltexte/2013/7664/pdf [accessed in Manila, Philippines: August 4, 2016].

Ato, J. (2002). "Knowledge, Awareness, and Practices of the Kauran National High School of Environmental Care". Unpublished Master's Thesis. Cotabato City, Philippines: Notre Dame University.

Babbie, E. (1999). The Basics of Social Research. Belmont, CA: Wadsworth Publishing Company.

Bailey, J. (2008). "First Steps in Qualitative Data Analysis: Transcribing”. Available online at: http:// fampra.oxfordjournals.org [accessed in Manila, Philippines: February 17, 2016].

Balmaceda, L. (2004). "The Environmental Awareness, Attitudes, and Practices of the Tingiuans". Unpublished Master's Thesis. Laoag City, Philippines: Mariano Marcos State University.

Barry, J. (1999). Environment and Social Theory. London: Routledge.

Bennett, A.J. (2000). "Environmental Consequences of Increasing Production: Some Current Perspectives" in Agriculture, Ecosystems and Environment, 82,

\footnotetext{
${ }^{7}$ Statement: We wish to confirm that our paper is not a product of plagiarism, and have not been submitted, reviewed as well as published by other scholarly journals.
}

pp.89-95. Available online also at: https://www. scribd.com/document/180415230/Bennett-2000Agriculture-Ecosystems-Environment [accessed in Manila, Philippines: April 16, 2016].

Brandon, P.S. \& P. Lombardi. (2011). Evaluating Sustainable Development in the Built Environment. Chichester, West Sussex, United Kingdom: John Wiley \& Sons Ltd., $2^{\text {nd }}$ edition.

Brown, N. (2000). "Environmental Advocacy in the Carribean: The Case of the Nariva Swamp, Trinidad". Available online at: http://www. canari.org/docs/nariva.pdf [accessed in Manila, Philippines: April 16, 2016].

Cadiao, L. (2009). "Development of Modular Package on Environmental Awareness Protection and Conservation". Unpublished Doctoral Dissertation. Taft Avenue, Manila: Philippine Normal University.

Calderon, J.F. \& E.C. Gonzales. (1993). Methods of Research and Thesis Writing. Mandaluyong City: National Book Store, Inc. and Quad Alpha Centrum Bldg.

Canarias, J. (2005). "Environmental Awareness Level of Selected Second Year High School Students: Bases for Development of Lesson Exemplars for Teachers". Unpublished Master's Thesis. Taft Avenue, Manila: Philippine Normal University.

Codeniera, R. (2003). "Environmental Knowledge, Attitudes, and Practices of Teachers in ICM Elementary and High Schools in Cebu". Unpublished Master's Thesis. Manila, Philippines: Miriam College.

Davis, J. \& S. Elliott. (2003). Early Childhood Environmental Education: Making it Mainstream. Canberra: Early Childhood Australia.

Denzin, N.K. \& Y.S. Lincoln. (2003). Collecting and Interpreting Qualitative Materials. Thousand Oaks, California: Sage Publications, Inc.

Desa, A. et al. (2013). "Environmental Awareness and Education: A Key Approach to Solid Waste Management (SWM) - A Case Study of a University in Malaysia". Available online at: http://www.intechopen.com/books [accessed in Manila, Philippines: September 15, 2016].

Domingo, E.J. (2007). "Environmental Awareness, Attitudes, and Practices of High School Students". Unpublished Master's Thesis. Laoag City, Philippines: Mariano Marcos State University.

Dyson, T. \& C.Ó. Gráda. (2002). Demography, Food Production, and Famine Risks in the $21^{\text {st }}$ Century. Dublin: School of Economics, University College Dublin. Available online also at: http://irserver.ucd. ie/bitstream/handle/10197/486/ogradac [accessed in Manila, Philippines: October 5, 2016].

"Earth Day: The History of a Movement". Available online at: http://www.earthday.org/earthday-history-movement [accessed in Manila, 
Philippines: October 5, 2016].

"Encyclopedia of the Social and Cultural Foundations of Education, 2008". Available online at: http:// www.markfoster.net/struc/praxis.html [accessed in Manila, Philippines: October 5, 2016].

Enger \& Smith. (2013). Environmental Science: A Study of Interrelationships. New York: McGraw Hill, $13^{\text {th }}$ edition.

Erlich, P.R. (1968). The Population Bomb. New York: Rivercity Press, revised edition.

Everts, R. et al. (1996). Advocacy and Negotiation: A Process for Changing Institutional and Governmental Policies. Washington, D.C.: Center for Democratic Education.

Felipe, Z. San. (2003). “Extent of Integration of Environmental Education Concepts in the Physical, Biological, and Social Science Courses and Level of Awareness of Environmental Issues by Liberal Arts Students of State Colleges and Universities in Region V'. Unpublished Doctoral Dissertation. Manila, Philippines: Catanduanes State Colleges, Virac, Catanduanes.

Fontanilla, M.V. (2003). "Solid Waste Management Awareness and Practices of the Personnel and Students of the Divine World College of Vigan". Unpublished Master's Thesis. Manila: University of Northern Philippines.

Freire, P. (1972). Pedagogy of the Oppressed. New York: Heider and Heider .

Gallardo, A. (2008). "Waste Management Practices of Higher Education Institutions (HEIs): Implications for Packaging an Environmental Education Program". Unpublished Doctoral Dissertation. Manila, Philippines: Pamantasan ng Lungsod ng Maynila.

Gambro, J.S. \& H.N. Switzky. (1996). “A National Survey of Environmental Knowledge in High School Students: Levels of Knowledge and Related Variables" in Eric Document Reproduction Service, No.ED 379164.

Garcia, E. (1997). "Development and Validation of a Scale to Measure Environmental Awareness of College Freshmen at the Philippine Normal University". Unpublished Master's Thesis. Taft Avenue, Manila: Philippine Normal University.

Garcia, E. (2000). “The Initiatives on Environmental Protection and Preservation of South East Asian Countries: Prospect for Sustainable Development in the Region. Unpublished Doctoral Dissertation. Manila, Philippines: Centro Escolar University.

Gardner, G.T. \& P.C. Stern. (2002). Environmental Problems and Human Behavior. Boston: Pearson Custom Publishing, $2^{\text {nd }}$ edition.

Guzman, R.S. et al. (2000). Environmental Education for Sustainable Development. San Francisco: Wisdom Advocates Publishing.
Habermas, Jürgen. (1968). "The Idea of the Theory of Knowledge as Social Theory". Available online at: https://www.marxists.org/reference/archive/ habermas/1968/theory-knowledge.htm [accessed in Manila, Philippines: July 4, 2016].

Harris, F. (2004). Global Environmental Issue. Chichester, West Sussex, England: John Wiley \& Sons Ltd.

Hoffman, S.L. \& A. Bory-Adams. (2010). "The Human Capability Approach and Education for sustainable Development: Making the Abstract Real". Available online at: http://www.unece. org.unecedev.colo.iway.ch [accessed in Manila, Philippines: July 4, 2016].

Interview with Student A, in Manila, Philippines, on 9 February 2014.

Interview with Student B, in Manila, Philippines, on 9 February 2014.

Interview with Student $C$, in Manila, Philippines, on 9 February 2014.

Interview with Student D, in Manila, Philippines, on 9 February 2014.

Interview with Student E, in Manila, Philippines, on 9 February 2014.

Interview with Student F, in Manila, Philippines, on 16 February 2014.

Interview with Student G, in Manila, Philippines, on 16 February 2014.

Interview with Student $\mathrm{H}$, in Manila, Philippines, on 16 February 2014.

Interview with Student I, in Manila, Philippines, on 16 February 2014.

Interview with Student J, in Manila, Philippines, on 16 February 2014.

Interview with Principal A, in Manila, Philippines, on 23 February 2014.

Interview with Principal B, in Manila, Philippines, on 23 February 2014.

Interview with Teacher A, in Manila, Philippines, on 2 March 2014.

Interview with Teacher B, in Manila, Philippines, on 2 March 2014.

Interview with Teacher C, in Manila, Philippines, on 2 March 2014.

Interview with Teacher D, in Manila, Philippines, on 9 March 2014.

Interview with Teacher E, in Manila, Philippines, on 9 March 2014.

Interview with Teacher F, in Manila, Philippines, on 9 March 2014.

Interview with Parent A, in Manila, Philippines, on 16 March 2014.

Interview with Parent B, in Manila, Philippines, on 16 March 2014.

Interview with Parent $\mathrm{C}$, in Manila, Philippines, on 16 March 2014. 
Interview with Parent D, in Manila, Philippines, on 23 March 2014.

Interview with Parent E, in Manila, Philippines, on 23 March 2014.

Interview with Principal C, in Manila, Philippines, on 30 March 2014.

Interview with Principal D, in Manila, Philippines, on 30 March 2014.

Kaur, J. \& R. Kaur. (2013). "Environmental Awareness of Secondary and Senior Secondary Students". Available online at: http://www.aiaer. net/ejournal/vol21109/15.\%20Kaur $\% 20 \& \% 20$ Kaur.pdf [accessed in Manila, Philippines: August 4, 2016].

Louka, E. (2006). International Environmental Law: Fairness, Effectiveness, and World Order. New York: Cambridge University Press.

Madsen, P. (1996). Earth Summit Ethics: Toward a Reconstructive Postmodern Philosophy of Environmental Education. New York: Albany State University of New York Press.

Mani, M. (2006). "Training Package in Promoting Environmental Awareness for the Local Government Units and the Parent Teachers and Community Association Groups in the Division of Romblon". Unpublished Master's Thesis. Manila, Philippines: Eulogio "Amang" Rodriguez Institute of Science and Technology.

Miranda, N. (2008). "An Assessment of the Current Environmental Management of Miriam College". Unpublished Master's Thesis. Manila, Philippines: Miriam College.

Moralda, E. (2003). "Environmental Awareness, Attitudes, and Practices of Fourth Year High School Students in St. Theresa's College, Cebu City". Unpublished Master's Thesis. Manila, Philippines: Miriam College.

Mukherjee, R. (2012). Environmental Management and Awareness Issues. New Delhi: Sterling Publishers Private Limited.

Norris, J. (2013). "Waste Management Awareness and Practices of Students at SSC-R Cavite". Unpublished Master's Thesis. Manila: Philippine Normal University.

Obar, J.A. et al. (2012). “Advocacy 2.0: An Analysis of How Advocacy Groups in United States Perceive and Use Social Media as Tools for Facilitating Civic Engagement and Collective Action". Available online at: http://jip.vmhost.psu. edu/ojs/index.php/jip/article [accessed in Manila, Philippines: October 14, 2016].

Ofreneo, R. (2012). Green Jobs and Green Skills in a Brown Philippine Economy. Diliman, Quezon City: The UP [University of Philippines] Press.

Opschoor, J.B. \& R.K. Turner. (1994). Environmental Economics and Environmental Policy Instruments:
Introduction and Overview. Netherlands: Kluwer Academic Publishers.

Palmer, J. \& P. Neal. (1994). The Handbook of Environmental Education. London: Routledge.

Paringit, N. (2012). “How 'Green' are You?: Profiling Green Consumers in Rizal Province and Metro Manila". Unpublished Master's Thesis. Manila, Philippines: Miriam College.

Pope, C., S. Ziebland \& N. Mays. (2000). "Qualitative Research in Health Care: Analysing Qualitative Data" in British Medical Journal, 320(7227), pp.114-116.

Primack, B. (2004). A Primer of Conservation Biology. Sunderland, USA [United States of America]: Sinauer Associates, Inc., third edition.

Raven, P. et al. (2010). Environment. New York: John Wiley \& Sons, Inc., $7^{\text {th }}$ edition.

Reyes, L. (2009). 'Philippines: Typhoon 'Ondoy' Death Toll Reaches 243". Available online at: http://digitaljournal.com/article/279910 [accessed in Manila, Philippines: July 7, 2016].

Robottom, I.M. \& P. Hart. (1993). Research in Enviromental Education. Victoria: Deakin University Press.

Rossman, G.B. \& S.F. Rallis (2003). Learning in the Field: An Introduction to Qualitative Research. Thousand Oaks, CA: Age Publication, 2nd edition.

Saldana, J. (2008). "An Introduction to Codes and Coding”. Available online at: http://www.sagepub. com/upm-data/24614 01 Saldana Ch 01.pdf [accessed in Manila, Philippines: February 16, 2016].

Santos, J.E. et al. (2000). "Environmental Education Praxis toward a Natural Area". Available online at: http://www.ceachile.cl/revista/cdn/GA\%206\%20 Santos\%20et $\% 20$ al.\%202000.pdf [accessed in Manila, Philippines: August 4, 2016].

Scott, W. \& S. Gough. (2003). Sustainable Development and Learning: Framing the Issues. London \& New York: Routledge Falmer.

Sengupta, M. et al. (2000). "Environmental Awareness and Environment Related Behaviour of Twelfth Grade Students in Kolkata: Effects of Stream and Gender". Available online at: http://rkmbcerahara. org/pdf/1270471914anwesa.pdf [accessed in Manila, Philippines: August 4, 2016].

Sering, L. (2013). "Ang Storm Surge o Daluyong”. Available online at: http://www.journal.com. ph/index.php/opinion [accessed in Manila, Philippines: November 26, 2016].

Sevilla, C.G. et al. (1984). An Introduction to Research Methods. Manila: Rex Bookstore, Inc.

Sharmin, L. (2003). "Assessment of Environmental Awareness of Students with Primary Education". Available online at: http://research.brac. net/reports/assessment [accessed in Manila, Philippines: August 4, 2016]. 
Snow, D.A. \& R.D. Benford. (1992). Frontiers in Social Movement Theory. New Haven, CT: Yale University Press.

Soriano, L. (1995). Save Mother Earth: What Schools Can Do. Quezon City: Phoenix publishing House, Inc.

Spehr, K. \& R. Curnow. (2011). "Community Change". Available online at: http://www. communitychange.com.au/insights-and-tools [accessed in Manila, Philippines: June 5, 2016].

“The Philippine Agenda 21". Available online at: http://emb.gov.ph/eeid/philagenda.htm [accessed in Manila, Philippines: August 4, 2016].

Tietenberg, T. (2006). Environmental Natural Resource Economics. New York: Pearson Education, Inc., $7^{\text {th }}$ edition.
Tilbury, D. (1995). "Environment Education for Sustainibility: Defining the New Focus of Eenvironment Education in 1990s" in Environment Education Research, 1(2), pp.195-212.

Valles, D.T. (2002). "Factors in the Involvement in Environmental Activities of Organization in Kotkot-Lusaran-Mananga Watershed, Cebu City". Unpublished Master's Thesis. Manila, Philippines: Miriam College.

Vega, V. et al. (2009). Social Dimensions of Education. Quezon City: Lorimar Publishing, Inc.

"World Youth Report in 2003". Available online at: http:// www.un.org/esa/socdev/unyin/documents/ch05.pdf [accessed in Manila, Philippines: October 14, 2016]. www.epa.gov/osw [accessed in Manila, Philippines: October 9, 2016]. 


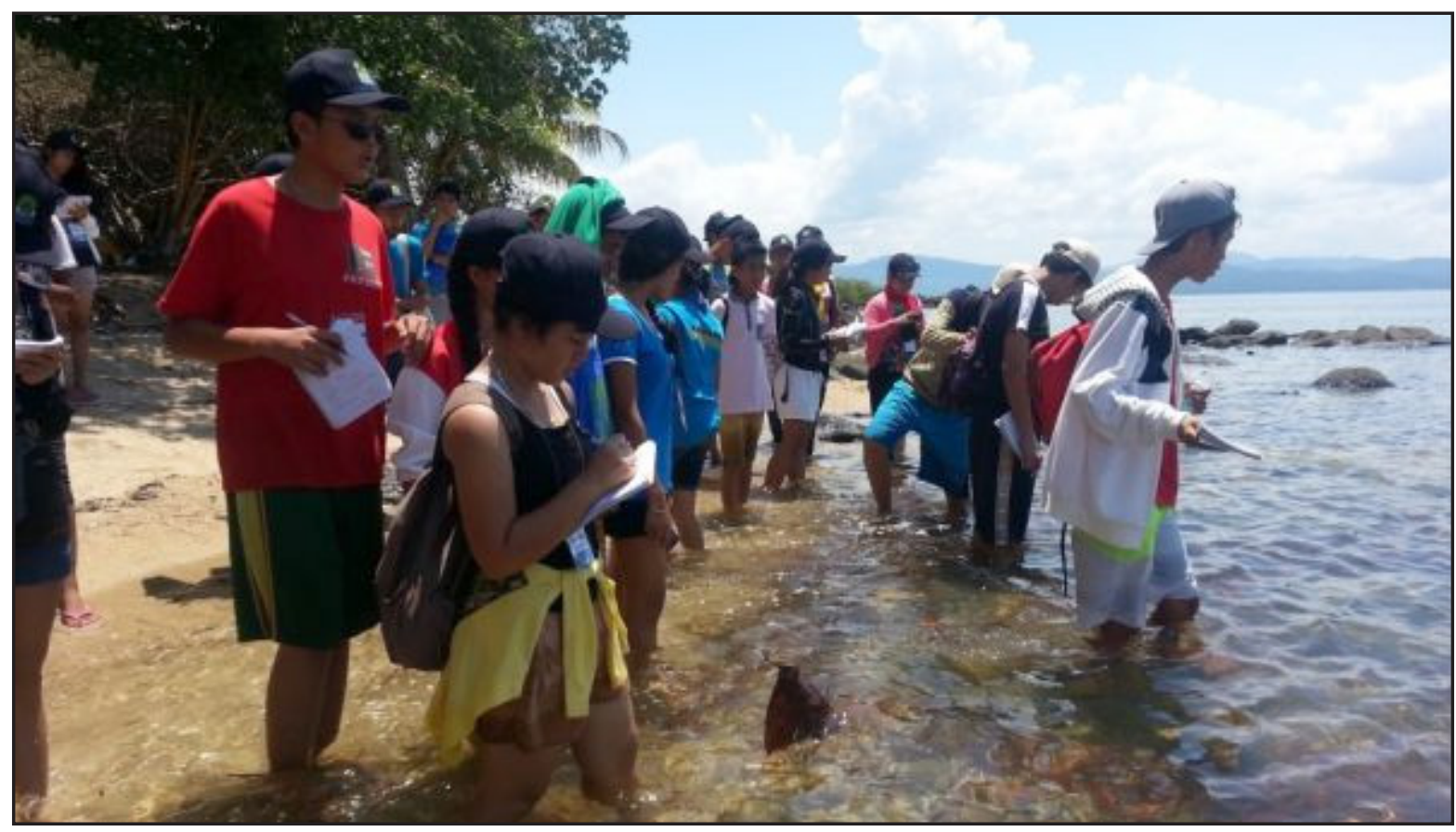

Students' Environmental Awareness and Practices in the Philippines

(Source: https://blogs.adb.org, 25/1/2017)

The Philippines is one of the countries that are facing environmental challenges and issues. Scenarios like floods due to heavy rain and poor solid waste disposal are just some of the reasons of environmental degradation. This can be easily gleaned from the list of environmental concerns which the DENR (Department of Environment and Natural Resources) does not tire in enumerating in its Annual Report other than what are being reported in the news at present. 